\title{
Comparison of multiple intelligence fields of physical education and sports college students
}

\author{
Didem Gulcin KEMEC
}

\author{
School of Physical Education and Sports, Gazi University, Ankara, Turkey. \\ This study is a part of D. G. Kemec's thesis. \\ Address correspondence to D. G. Kemeç, e-mail; didemkemec@gmail.com
}

\begin{abstract}
Aim of this study was to identify and compare the areas of multiple intelligence of School of Physical Education and Sports students according to some parameters. Research group consists of 185 people, chosen randomly, who studied at Sakarya and Gaziantep University School of Physical Education and Sports during the academic year of 2014-2015. In this research "SelfEvaluation Survey in Multiple İntelligence" developed by Gardner and adapted toTurkish and customized the validity and reliability of this survey by Saban was used as a data collection tool. "Anova Test" was used to determine the differences between intelligence scores, and "Tukey HSD Test" was used to define the different group. The data collected by using survey was analyzed by using Spss 21 for Windows package program. As a result of the this study, In contrast to students' social, physical, inherent and naturist intelligence, there is a significant difference between linguistic, visual and musical intelligence in favor of the female students and logical intelligence in favor of the males students. In addition linguistic intelligence of subjects was found significantly different according to their deparment variables. Logical, visual, physical, musical, social, inherent and naturist intelligence were found at the same level. School of Physical Education and Sports students were found significantly higher level of logical, visual, physical and naturist intelligence areas. Moreover, department of Sports Management students were showed higher level of linguistic, musical, social and inherent intelligence areas, in comparison to other School of Physical Education and Sports departments' students.
\end{abstract}

Keywords: School of Physical Education and Sports, Multiple Intelligences, Student.

\section{INTRODUCTION}

The concept of intelligence is not peculiar to students who are getting an education or a highrank worker. People make use of their intelligence throughout their daily lives such as walking, talking, shopping, etc.

Generally speaking, intelligence is considered as an ability to learn, indication is something that a person learns being more and more intelligent than the ones who learn less (17). Throughout centuries, scientists, psychologists, educational experts and others have discovered various aspects of intelligence. Piaget, for example, defined intelligence as the changes and innovations of the conscious mind, whereas Thorndike claimed that intelligence is three dimensional such as abstract intelligence, mechanical intelligence and social intelligence (19).

A learning specialist in the name of Howard Gardner stated that: Being a successful chess player, a violin virtuoso or even a successful athlete can come into our minds. These great minds do deserve special recognition. Do you think that these people are intelligent? Even if they are, how come our test cannot predict their intelligence? If even they are not smart what makes these people so successful? Speaking in general how these people with all their efforts can be so successful; do they take this into consideration? These have been taken into consideration and have been researched in different dimensions (9).

Also being taken into consideration, it has been researched and monitored of those who have suffered from accidents and suffered brain damage (23). After these various studies, in order to determine the different types of intellectual concepts, sorting them out into different categories and choosing the ones that's are suitable, Gardner and his colleagues first decided on the 7 intellectual concepts and afterwards adding another have theorized the multiple intelligence theory (23). In the 
scope of the multiple intelligence theory, spatial visual intelligence, bodily kinesthetic (physical) intelligence, naturalist, logical and mathematical intelligence are connected to our imaginations having us revive and animate these different intelligences. Verbal linguistic intelligence and musical intelligence, being independent in their own fields, have an acoustic structure and are patterning to each other. In the area of interpersonal intelligence we see the individual being more connected to each and being in communication with their surroundings (3). According to this research each person who is born has these eight intelligences; these intelligences can be improved over time (18).

The purpose of traditional intelligence is to solve problems and take into consideration of how individuals use traditional intelligence in the multiple intelligence theory, this being of the basis of this understanding (23). Having the individuals tested it shows us how they can be affected by their surroundings and the perspectives of their families. This also affects their success in the future as well (8). The multiple intelligence theory expresses the individual's intelligences and their criteria. If the individuals intelligence is not developed this theory proves that it can be developed. Instead of having them impressed and put into patterns, we can spread each of these intelligences into equal sections helping them improve their basis. If we can choose intelligence theory based on their specialties individuals will be able to come to a standard level (3).

We can see many differences according to the age, gender, education background, and the capacity of understanding. We can see individual differences of the person and their major intelligence can affect the less minor intelligence of the individual, this having a negative effect on the development of the individual. In this process we can give a great example on the existence of the field of intelligence and how it has a negative development; one of these being an impairment to the learning of a language. At the end of this observation we can see how there are different specialties (5).

At the end of the observation of these special gifted students the purpose of this study is to show the differences between the School of Physical Education and Sports, and the multiply intelligence theory can affect individuals according to different variances.

\section{MATERIAL \& METHOD}

In this research the students of School of Physical Education and Sports have been taken into a descriptive survey model according to gender, age, major, and class. The descriptive survey modal is used as a modal that has many students participate despite their variances, this helps us reach a decision in an universal environment, it also helps us put the participies in a group according to the survey that has been done (13).

According to the survey between the years of 2014-2015 there are a total of 1540 students at the University of Gaziantep and Sakarya, at the ages of 18 or above, and different genders at the Department of Physical Education and Sports Faculty.

In the examples of the study between the years of 2014-2015 in the spring semester at the University of Gaziantep and Sakarya with the participation of 1, 2, 3 and 4 levels students, a total of 185 students have participated voluntarily from the Department of Physical Education and Sports Faculty in this survey.

In this research, in order to specify the SelfAssessment Inventory in Multiple Intelligence Areas Theory which has been developed by Gardner and translated into Turkish by Saban is consisted of 10 questions learning on the 8 intelligence fields with a total of 80 questions. In this research, the survey is consisted of 8 intelligence fields which are the following: verbal, logical, visual, musical, physical, social, conservationist and internal intelligence. The survey's inventory consists of the following 5 rating system: $0=$ not suitable, $1=$ rarely suitable, $2=$ less suitable, $3=$ somewhat suitable, $4=$ completely suitable. The intelligence fields are consisted of the following: 33-40 are highly advanced, 25-32 are advanced, 9-16 are average, and $0-8$ is underdeveloped.

Anova Test was used to determine the differences between intelligence scores, and Tukey HSD Test was used to define the different group, and $\alpha=0.05$ was based on as level of significance. The data collected by using survey was analyzed by using Spss 21 for Windows package program. 


\section{RESULTS}

In Table 1, the following students have participated from the department of Physical Education and Sports Department which are the follow: 29.2\% Physical Education Teaching, 28.6\% Coaching Education, 30.3\% Sports Management, $11.9 \%$ Recreation Education. $50.3 \%$ of the participants are female, $49.7 \%$ is male.

As shown in Table 2, the student's age participating in the research, verbal $(\mathrm{r}=.087, \mathrm{p}=.240)$, logical $(\mathrm{r}=.138, \mathrm{p}=.061)$, visual $\quad(\mathrm{r}=-.045, \mathrm{p}=.547)$, natural $(\mathrm{r}=.131, \mathrm{p}=.075)$, social $(\mathrm{r}=-.070, \mathrm{p}=.343)$, social $(\mathrm{r}=-.058, \mathrm{p}=.434)$ ve internal $(\mathrm{r}=-.022, \mathrm{p}=.763)$ while there is no logical meaning between the IQ score, there is negative relationship between the musical logical ( $\mathrm{r}=-.012, \mathrm{p}=.820)$.
As shown in Table 3, the number of females participating in the research gender $(\mathrm{F}=4.685$, $\mathrm{p}=.032<.05)$ and major variances ( $\mathrm{F}=3.902$, $\mathrm{p}=.010<.05$ ) have shown no differences. The students in the Department of Physical Education and Sports who have switched majors and the students who have taken the "Tukey HSD Test" have shown discrepancy difference of the IQ scores. According to the gender variances logical $(\mathrm{F}=7.216, \mathrm{p}=.008<.05)$, visual $(\mathrm{F}=7.031, \mathrm{p}=.009<.05)$ and musical $(\mathrm{F}=12.218$, $\mathrm{p}=.001<.05$ ) have shown no difference in the IQ scoring section.

As shown in Table 4, the number of students participating in the research gender and intelligence varriances have shown no difference in the IQ scoring section.

Table 1. The frequency bar charts of the students participating from the physical education and sports department.

\begin{tabular}{lllll}
\hline Variables & Sub-Categories & $\mathrm{n}$ & $\%$ & Total \\
\hline \multirow{5}{*}{ Department } & Physical Education and Sports Teacher & 54 & 29.2 & \\
& Coaching Education & 53 & 28.6 & \\
& Sports Management & 56 & 30.3 & 185 \\
& Recreation Education & 22 & 11.9 & \\
\multirow{5}{*}{ Gender } & Female & 93 & 50.3 & \multirow{2}{*}{185} \\
& Male & 92 & 49.7 & \\
\hline
\end{tabular}

Table 2. The IQ scores of the students participating students from the physical education and sports department (Pearson Correlation Coefficient).

\begin{tabular}{lcccccccc}
\hline & Linguistic & Logical & Visual & Musical & Naturist & Social & Physical & Inherent \\
\hline Pearson Correlation & .087 & .138 & -.045 & -.148 & .131 & -.070 & .058 & -.022 \\
Sig. (2-tailed) & .240 & .061 & .547 & $.044^{*}$ & .075 & .343 & .434 & .763 \\
$\mathrm{~N}$ & 185 & 185 & 185 & 185 & 185 & 185 & 185 & 185 \\
\hline
\end{tabular}


Table 3. The IQ comparison of the students of the department of physical education and sport department Verbal Linguistic, Logical - Mathematical, Visual - Spatial and Musical- Rhythmic Intelligences comparisons (Dual factor Anova Test).

\begin{tabular}{|c|c|c|c|c|c|c|c|c|}
\hline Intelligence Areas & Gender & Department & $\mathrm{N}$ & Mean & $\mathrm{SD}$ & Variables & $\mathrm{F}$ & $\mathrm{P}$ \\
\hline \multirow{15}{*}{ Verbal-Linguistic Intelligence } & \multirow{6}{*}{ Female } & Teaching Öğretmenliği & 28 & 27.89 & 5.520 & \multirow{6}{*}{ Gender } & \multirow{6}{*}{4.685} & \multirow{6}{*}{$.032 *$} \\
\hline & & Coaching & 26 & 23.77 & 6.383 & & & \\
\hline & & Management & 28 & 28.82 & 5.186 & & & \\
\hline & & Reacreation & 11 & 27.73 & 6.182 & & & \\
\hline & & Total & 93 & 27.00 & 6.027 & & & \\
\hline & & Teaching & 26 & 26.15 & 4.839 & & & \\
\hline & \multirow{3}{*}{ Male } & Coaching & 27 & 24.19 & 6.165 & \multirow{4}{*}{ Department } & \multirow{4}{*}{3.902} & \multirow{3}{*}{$.010^{*}$} \\
\hline & & Management & 28 & 25.54 & 4.582 & & & \\
\hline & & Reacreation & 11 & 24.82 & 4.579 & & & \\
\hline & \multirow{6}{*}{ Total } & Total & 92 & 25.23 & 5.142 & & & \\
\hline & & Teaching & 54 & 27.06 & 5.228 & \multirow{5}{*}{$\begin{array}{l}\text { Department* } \\
\text { Gender }\end{array}$} & \multirow{5}{*}{1.141} & \multirow{5}{*}{.334} \\
\hline & & Coaching & 53 & 23.98 & 6.216 & & & \\
\hline & & Management & 56 & 27.18 & 5.124 & & & \\
\hline & & Reacreation & 22 & 26.27 & 5.513 & & & \\
\hline & & Total & 185 & 26.12 & 5.659 & & & \\
\hline \multirow{15}{*}{$\begin{array}{l}\text { Logical-Mathematical } \\
\text { Intelligence }\end{array}$} & & Teaching & 28 & 22.68 & 8.129 & & & \\
\hline & & Coaching & 26 & 17.38 & 7.200 & & & \\
\hline & Female & Management & 28 & 20.82 & 9.573 & Gender & 7.216 & $.008 *$ \\
\hline & & Reacreation & 11 & 17.64 & 5.297 & & & \\
\hline & & Total & 93 & 20.04 & 8.271 & & & \\
\hline & & Teaching & 26 & 23.12 & 8.131 & & & \\
\hline & & Coaching & 27 & 21.41 & 7.469 & & & \\
\hline & Male & Management & 28 & 22.68 & 6.689 & Department & 1.893 & .132 \\
\hline & & Reacreation & 11 & 24.55 & 7.090 & & & \\
\hline & & Total & 92 & 22.65 & 7.339 & & & \\
\hline & & Teaching & 54 & 22.89 & 8.056 & & & \\
\hline & & Coaching & 53 & 19.43 & 7.546 & & & \\
\hline & Total & Management & 56 & 21.75 & 8.236 & Department* & 1.106 & .348 \\
\hline & & Reacreation & 22 & 21.09 & 7.057 & & & \\
\hline & & Total & 185 & 21.34 & 7.909 & & & \\
\hline & & Teaching & 28 & 31.96 & 5.764 & & & \\
\hline & & Coaching & 26 & 30.96 & 5.126 & & & \\
\hline & Female & Management & 28 & 31.89 & 6.280 & Gender & 7.031 & $.009 *$ \\
\hline & & Reacreation & 11 & 30.82 & 7.305 & & & \\
\hline & & Total & 93 & 31.53 & 5.875 & & & \\
\hline & & Teaching & 26 & 31.23 & 5.324 & & & \\
\hline & & Coaching & 27 & 26.89 & 7.084 & & & \\
\hline Visual-Spatial Intelligence & Male & Management & 28 & 28.79 & 5.934 & Department & 1.805 & .148 \\
\hline & & Reacreation & 11 & 28.55 & 6.056 & & & \\
\hline & & Total & 92 & 28.89 & 6.275 & & & \\
\hline & & Teaching & 54 & 31.61 & 5.516 & & & \\
\hline & & Coaching & 53 & 28.89 & 6.477 & & & \\
\hline & Total & Management & 56 & 30.34 & 6.253 & Department* & .727 & .537 \\
\hline & & Reacreation & 22 & 29.68 & 6.650 & & & \\
\hline & & Total & 185 & 30.22 & 6.203 & & & \\
\hline & & Teaching & 28 & 29.86 & 7.541 & & & \\
\hline & & Coaching & 26 & 27.54 & 7.458 & & & \\
\hline & Female & Management & 28 & 29.39 & 6.822 & Gender & 12.218 & $.001^{*}$ \\
\hline & & Reacreation & 11 & 29.55 & 6.948 & & & \\
\hline & & Total & 93 & 29.03 & 7.185 & & & \\
\hline & & Teaching & 26 & 25.62 & 7.548 & & & \\
\hline & & Coaching & 27 & 23.59 & 6.488 & & & \\
\hline Musical-Rhythmic & Male & Management & 28 & 26.43 & 8.153 & Department & 1.142 & .334 \\
\hline Intelligence & & Reacreation & 11 & 24.45 & 7.118 & & & \\
\hline & & Total & 92 & 25.13 & 7.370 & & & \\
\hline & & Teaching & 54 & 27.81 & 7.773 & & & \\
\hline & & Coaching & 53 & 25.53 & 7.194 & & & \\
\hline & Total & Management & 56 & 27.91 & 7.597 & Department* & .134 & .939 \\
\hline & & Reacreation & 22 & 27.00 & 7.342 & Gender & & \\
\hline & & Total & 185 & 27.09 & 7.516 & & & \\
\hline
\end{tabular}


Table 4. The comparison of the students of the physical education and sports department according to the gender and the naturist, social, physical, and internal intelligences (Dual factor Anova Test).

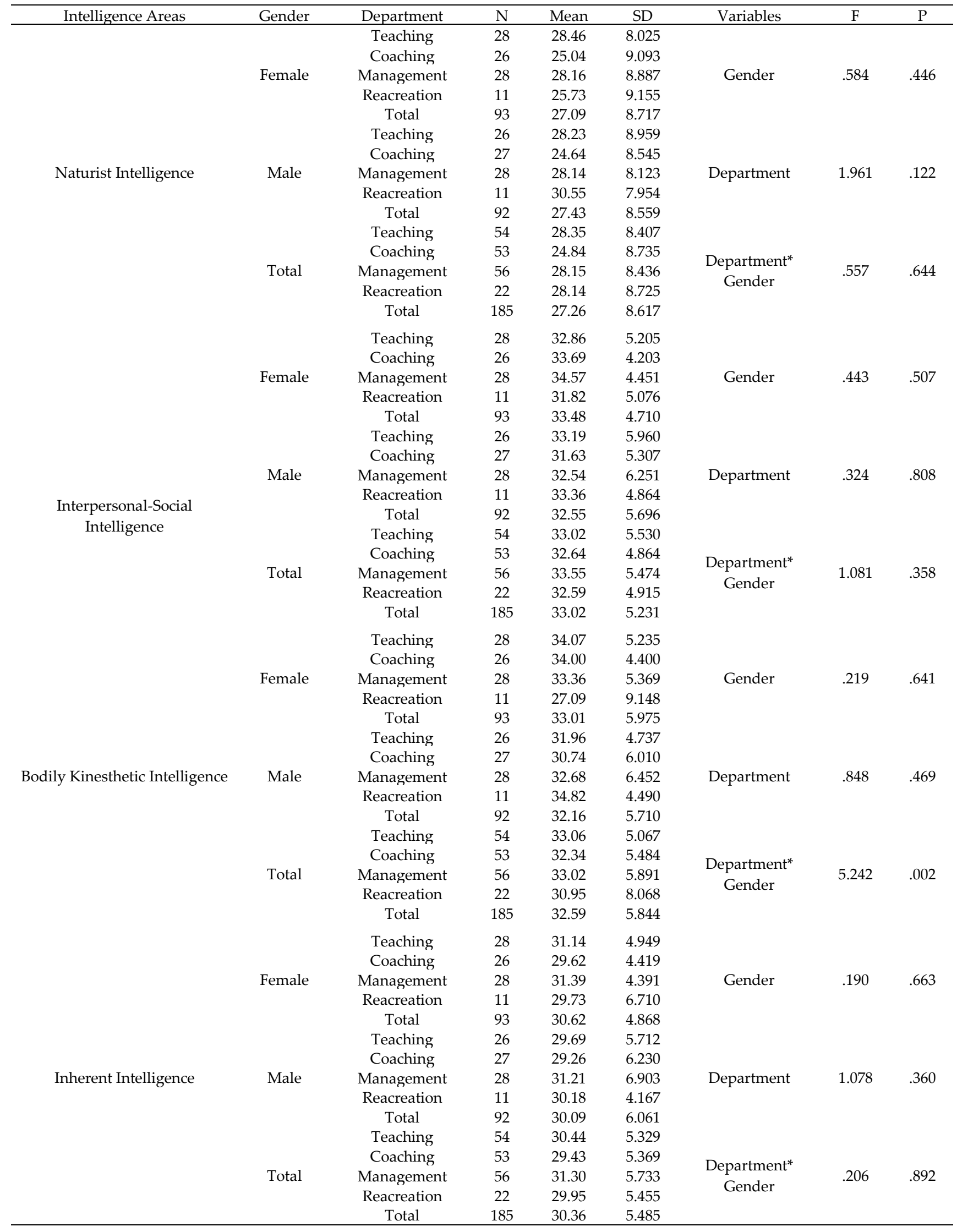




\section{DISCUSSION}

While there isn't any kind of relationship between the students of Physical Education and Sports Department in the intelligence areas of verbal, logical, visual, social, physical, internal, and natural intelligences however, we have discovered that there is weak and strong relationship in the musical intelligence area also seeing a negative effect between the students.

Between the intelligence areas of athletes in the study of Altınmakas (1), we have come to a conclusion that there is a weak relationship between the students with physical intelligences in a negative way and how their ages are in effect.

In Table 3, there is a major difference between the students that are well in the verbal, logical, visual and musical intelligence area. According to the variances there is a major difference between genders in the verbal, logical, musical, and visual intelligences; there is also a male countenance to the female students. There is a major verbal intelligence difference between the students who are in Coaching Education to Physical Education and Sports Teaching, this also shows that there is a logical and musical intelligence between Physical Education and Sports Teaching, also there is verbal and musical difference between the intelligence areas of the students at the Physical and Education and Sports Department.

In the studies Ürgüp (22) has shown major differences in the study $(\mathrm{p}<0,05)$; while Güllü and Tekin (10) are have shown a higher IQ $(X=26,34)$ compared to the general of high school students in the verbal intelligence area. $(X=23,41)$ Studies done by Tekin (20) the students who are is in an intermediate level according to the gender variances have shown a major difference in the logical intelligence areas, also Altınok (2), according to the switching of majors have shown a difference in the

At the end of this study we have found variances between the students with different genders with verbal, visual, and musical intelligences for the female students, while logical intelligences has been found for the male students. According to the research students who have switched majors have shown a greater improvement than the Physical Education and Sports Teaching and the School of Physical Education and Sports Department. While not finding any differences between the age and the IQ of the students, we have logical intelligence area. According to Hoşgörür and Katrancl (11) major differences have been discovered according of the students in the field of visual intelligence and gender in the Physical Education and Sports Department $(\mathrm{t}=2.144 ; \mathrm{p}<0.05)$. Tural (21) has come to the conclusion of not finding any variances in the visual intelligence area. The research that has been done by İzci and Sucu (12) showed a difference in the musical intelligence area according to gender. $(p<0,05)$. Altınok (2) has come to conclusion that there isn't a difference in the musical intelligence area of the students in this department.

In Table 4, there isn't any variances between the students according to the natural, social, physical and internal intelligences. There is a difference between the genders between the male students who have natural and internel intelligences among the male students, while there is a major difference between the students of physical education and sports department with the physical and natural intelligents.

According to Çinkıliç and Soyer (4) there is a difference between the prospect students with natural intelligences $(t=1,090 ; p=0,278>0,05)$. Kartal (14) has found a difference among students who do and don't sports. Tekin (20) and Altınok (2) has come to the conclusion that students $(p>0.05)$; who don't do sports haven't shown any differences. Kaya and friends (15) came to the conclusion that students with physical intelligences haven't shown any differences in any intelligence fields. Ermiş and friends (7) haven't found any differences between the students of School of Physical Education and Sports and Police Vocational School of Higher Education in their IQ scores. Ermiş (6) the study of the students who play sports according to gender variable $(\mathrm{p}=0,521) \quad(\mathrm{t}=0,643)$; and Tural $(21)$ haven't found any differences in internal intelligences of the students.

come to a conclusion that the students with musical intelligence have shown a negative effect.

The studens of School of Physical Education and Sports have shown great improvement in the variances of the 8 intelligence fields, this being in order of social, physical, internal, and visual, while the lowest being logical, and verbal. While being recorded by Kul and friends (16) the prospect students of School of Physical Education and Sports having the greater intelligence fields which are social and physical while the lowest being verbal 
and musical. These studies have proven to be parallel. Also it shows that females have a higher IQ score than the males. It has also showed that the students that are in sport teaching and sports management majors have an higher IQ than those who are in School of Physical Education and Sports.

\section{REFERENCES}

1. Altınmakas O. Examining the multiple intelligence distribution of professional basketball players in means of the positions on the team. Master Thesis, Institute of Educational Sciences, Gazi University, Ankara, 2011.

2. Altınok E. Examine of multiple intelligence areas on physical education students according to some variables. Graduation Thesis, Institute of Health Sciences, Selçuk University, Konya, 2008.

3. Bümen NT. Okulda Çoklu Zekâ Kuramı, Pegem A Yayıncılık, Ankara, 2005.

4. Çinkılıç İ, Soyer F. An investigation the relation between multiple intelligence areas of pre-service physical education teacher and their problem solving skills. Spor Yönetimi ve Bilgi Teknolojileri Dergisi (Elektronik Dergi), 2013; 8(1): 4-16.

5. Demirel Ö. (Ed.). Eğitimde Yeni Yönelimler, Pegem A Yayıncilık, Ankara, 2007.

6. Ermiş E. A comparison of the multiple intelligences of university students who do sports regularly and the students do not in terms of specific variables. Doctoral Thesis, Institute of Health Sciences, Ondokuz Mayıs University, Samsun, 2012.

7. Ermiş E, İmamoğlu O, Erilli NA. The effect of sports on the bodily-kinesthetics and interpersonal multiple intelligences scores of university students. Journal of Sports and Performance Researches, 2012; 3(2): 23-29.

8. Gardner H. Zihin Çerçeveleri, Alfa Yayıncılık, İstanbul, 2004.

9. Gardner H. Çoklu Zekâ Yeni Ufuklar, Optimist Yayınları, İstanbul, 2013.

10. Güllü M, Tekin M. Comparison of multiple intelligence areas of students at sports high schools and public high schools. Niğde University Journal of Physical Education and Sport Sciences, 2009; 3(3): 247-258.

11. Hoşgörür V, Katrancı M. The dominant field of the students in the department of elementary education and physical education and sports (A sample of education faculty of university of Kırıkkale). Ondokuz Mayıs Üniversitesi Eğitim Fakültesi Dergisi, 2007; 24: 33-42.
12. İzci H, Sucu HÖ. İnvestigating multiple intelligence profiles of university students (Nevşehir University Sample). Inönü University Journal of Educational Science Institute, 2014; 1(1): 12-21.

13. Karasar N. Bilimsel Araştırma Yöntemi, Nobel Yayın Dağıtım, Ankara, 2009.

14. Kartal B. The comparison of student athletes in different sports and sedentary students according to multiple intelligent theory. Master Thesis, Institute of Educational Sciences, Karadeniz Teknik University, Trabzon, 2012.

15. Kaya HB, Karakaş G, Gizdem S. Examining the relationship between physical/kinesthetic intelligence and academic successes of physical education and sport students. Celal Bayar University Journal of Physical Education and Sport Sciences, 2015; 10(1): 66-74.

16. Kul M, Bozkuş T, Erol Z, Elçi G. A research on the comparison of the multiple intelligence types of the candidates who succeeded and failed in the entrance exams of physical education and sports school. International Journal of Science Culture and Sport, 2014; July: Special Issue 1: 891897.

17. Özgüven E. Zekâ Nedir?, Milli Eğitim Bakanlığı Talim ve Terbiye Dairesi Test ve Araştırma Bürosu, Ankara, 1961.

18. Saban A. Çoklu Zekâ Kuramı ve Türk Eğitim Sistemine Yansıması, Nobel Yayın Dağıtım, Ankara, 2010.

19. Selçuk Z, Kayılı H, Okut L. Çoklu Zekâ Uygulamaları, Nobel Yayın Dağıtım, Ankara, 2003.

20. Tekin M. The searching of creativity and multiple intelligences areas between the students in the high school level students who do sports and those who don't. Doctoral Thesis, Institute of Educational Sciences, Gazi University, Ankara, 2008.

21. Tural M. Section of physical education and sport in college students according to the comparison of the multiple intelligence theory. Master Thesis, Institute of Educational Sciences, Gazi University, Ankara, 2009.

22. Ürgüp S. Investigating of multiple intelligences of students in three different departments of the school of physical education and sports. Master Thesis, Institute of Health Sciences, Cumhuriyet University, Sivas, 2015.

23. Yavuz KE. Eğitim ve Öğretimde Çoklu Zekâ Teorisi ve Uygulamaları, Ceceli Yayınları, Ankara, 2004. 